\title{
Status of the Ground Water FLOW MODEL FOR THE UMTRA Project Shiprock, New Mexico, SITE
}

January 1995 


\section{INTENDED FOR PUBLIC RELEASE}

This report has been reproduced from the best available copy. Available in paper copy and microfiche.

Number of pages in this report: 44

DOE and DOE contractors can obtain copies of this report from:

Office of Scientific and Technical Information

P.O. Box 62

Oak Ridge, TN 37831

(615) 576-8401

This report is publicly available from:

National Technical Information Service

Department of Commerce

5285 Port Royal Road

Springfield, VA 22161

(703) $487-4650$ 


\section{DISCLAIMER}

Portions of this document may be illegible in electronic image products. Images are produced from the best available original document. 
Prepared for

U.S. Department of Energy UMTRA Project Office Albuquerque, New Mexico

Prepared by Jacobs Engineering Group Inc. Albuquerque, New Mexico

\section{DISCLAIMER}

This report was prepared as an account of work sponsored by an agency of the United States Government. Neither the United States Government nor any agency thereof, nor any of their employees, makes any warranty, express or implied, or assumes any legal liability or responsibility for the accuracy, completeness, or usefulness of any information, apparatus, product, or process disclosed, or represents that its use would not infringe privately owned rights. Reference herein to any specific commercial product, process, or service by trade name, trademark, manufacturer, or otherwise does not necessarily constitute or imply its endorsement, recommendation, or favoring by the United States Government or any agency thereof. The views and opinions of authors expressed herein do not necessarily state or reflect those of the United States Government or any agency thereof. 


\section{EXECUTIVE SUMMARY}

A two-dimensional numerical model was constructed for the alluvial aquifer in the area of the Uranium Mill Tailings Remedial Action (UMTRA) Project Shiprock, New Mexico, site. This model was used to investigate the effects of various hydrologic parameters on the evolution of the ground water flow field. Results of the model are useful for defining uncertainties in the site conceptual model and suggesting data collection efforts to reduce these uncertainties.

The alluvial aquifer at the site lies on the floodplain of the San Juan River, with a bedrock escarpment truncating the aquifer along its western border. The San Juan River forms a continuous boundary along the eastern side of the alluvial aquifer. The primary source of inflow to the aquifer is leakage from the San Juan River. A flowing artesian well on the plateau above the escarpment also contributes to the aquifer system at Bob Lee Wash. Rainfall recharge and leakage from the Mancos Shale are also possible sources of water, but the volume of these components is unknown.

The computer code MODFLOW was used to simulate the two-dimensional flow of ground water in the alluvium. The escarpment was represented as a no-flow boundary. The San Juan River was represented with the MODFLOW river package. A uniform hydraulic conductivity distribution with the value estimated by the UMTRA Project Technical Assistance Contractor (TAC) and a uniform recharge distribution was used. Infiltration from the flowing artesian well was represented using the well package.

The ground water flow model was calibrated to ground water levels observed in April 1993. Inspection of hydrographs shows that these levels are representative of typical conditions at the site.

The modeling analysis shows that, in the absence of site-specific hydraulic conductivity data and more detailed data on the ground water flow field, considerable uncertainty exists in the relative contributions of the various ground water sources to the system. Because relatively little data other than measurements of hydraulic head exist, the problem of nonuniqueness (the equally good replication of the ground water flow field with many alternate combinations of parameters) is extreme. The current model cannot be considered an accurate tool to predict aquifer response to remediation, but is useful for testing various conceptual representations of the aquifer system.

Additional data are required to better define the hydrogeologic system. These data needs include installing additional monitor wells near the San Juan River to better assess its influence; monitoring the San Juan River stages; mapping the Mancos Shale underlying the alluvium; alluvium hydraulic conductivity studies; and quantifying the infiltration from Bob Lee Wash and leakage from the Mancos Shale. 
TABLE OF CONTENTS

Section

Page

1.0 INTRODUCTION ..........................1 1-1

1.1 Background ........................... 1-1

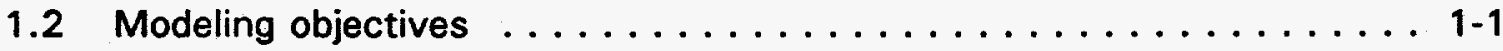

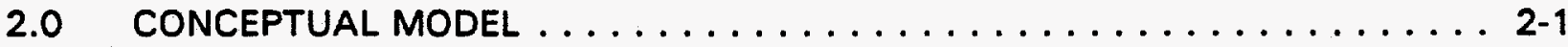

2.1 Stratigraphy ............................. 2-1

2.2 Hydraulic properties ........................ 2-5

2.3 Sources and sinks . . . . . . . . . . . . . . . . . 2-5

2.4 Ground water flow directions . . . . . . . . . . . . . . . 2-7

3.0 GROUND WATER FLOW MODEL CONSTRUCTION . . . . . . . . . . . . . 3-1

3.1 Code selection ..............................

3.2 Model discretization ...................... $\ldots \ldots$

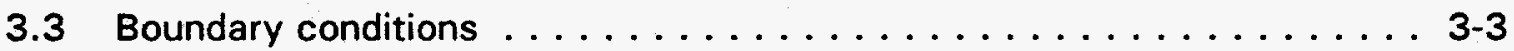

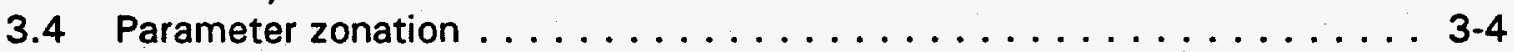

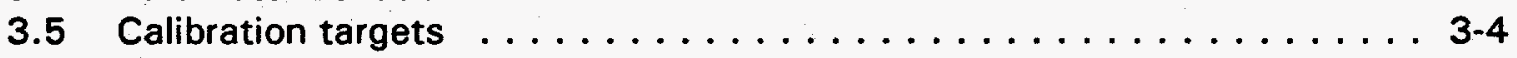

4.0 GROUND WATER FLOW MODEL CALIBRATION . . . . . . . . . . . . . . 4-1

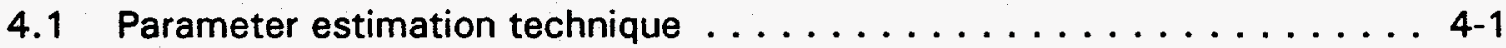

4.2 Calibration results . . . . . . . . . . . . . . . . . 4-2

5.0 GROUND WATER FLOW MODEL ANALYSIS $\ldots \ldots \ldots \ldots \ldots \ldots \ldots \ldots$

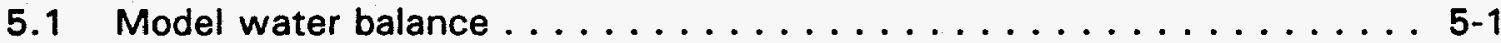

6.0 DISCUSSION AND CONCLUSIONS $\ldots \ldots \ldots \ldots \ldots \ldots \ldots \ldots \ldots$

$7.0 \quad$ LIST OF CONTRIBUTORS $\ldots \ldots \ldots \ldots \ldots \ldots \ldots \ldots \ldots \ldots$

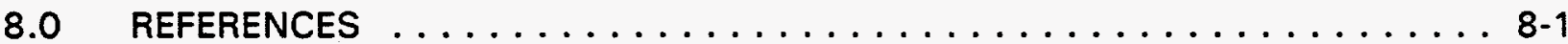


LIST OF FIGURES

Figure

Page

2.1 Shiprock site location map, Shiprock, New Mexico . . . . . . . . . . . . 2-2

2.2 Aerial view of Shiprock site in operating period, Shiprock, New Mexico, site .. 2-3

2.3 Top of Mancos Shale on floodplain, Shiprock, New Mexico, site . . . . . . . 2-4

2.4 Generalized cross section A-A', Shiprock, New Mexico, site . . . . . . . . . . 2-6

2.5 Ground water table contours and gradient on floodplain, Shiprock, New Mexico, site ......................... 2-8

3.1 Ground water flow model, Shiprock, New Mexico, site . . . . . . . . . . 3-2

4.1 Sensitivity of hydraulic conductivity to Bob Lee Wash infiltration, Shiprock, New Mexico, site ............................ 4-3

4.2 Sensitivity of model calibration to recharge and Bob Lee Wash infiltration, Shiprock, New Mexico, site ........................ 4-4

4.3 Simulated water table with residuals, high recharge case, Shiprock, New Mexico, site . . . . . . . . . . . . . . . . . . . . 4-6

4.4 Simulated water table with residuals, increased river stage, low recharge, Shiprock, New Mexico, site . . . . . . . . . . . . . . . . . . . 4-7

4.5 Observed versus simulated water levels, Shiprock, New Mexico, site . . . . . 4-8

6.1 Model application process, Shiprock, New Mexico, site . . . . . . . . . . 6-3 


\section{LIST OF TABLES}

Table

Page

3.1 Calibration target locations and values, Shiprock, New Mexico, site . . . . . 3-5

4.1 Observed versus calculated water levels, Shiprock, New Mexico, site . . . . . . 4-9

4.2 Summary calibration statistics, Shiprock, New Mexico, site . . . . . . . . . . 4-9

5.1 Simulated water balance, Shiprock, New Mexico, site . . . . . . . . . . 5-1 


\section{LIST OF ACRONYMS AND ABBREVIATIONS}

\begin{tabular}{|c|c|}
\hline Acronym & Definition \\
\hline $\mathrm{cm}$ & centimeter \\
\hline $\mathrm{cm} / \mathrm{s}$ & centimeters per second \\
\hline $\begin{array}{l}\text { DOE } \\
\mathrm{ft}\end{array}$ & $\begin{array}{l}\text { U.S. Department of Energy } \\
\text { foot }\end{array}$ \\
\hline $\mathrm{ft}^{2}$ & $\begin{array}{l}\text { toot } \\
\text { square feet }\end{array}$ \\
\hline $\mathrm{ft} / \mathrm{day}$ & feet per day \\
\hline $\mathrm{ft}^{3} /$ day & cubic feet per day \\
\hline $\begin{array}{l}\mathrm{gpm} \\
\mathrm{km}\end{array}$ & $\begin{array}{l}\text { gallons per minute } \\
\text { kilometer }\end{array}$ \\
\hline $\mathrm{km}^{2}$ & square kilometers \\
\hline $\mathrm{L} / \mathrm{min}$ & liters per minute \\
\hline $\mathrm{m}$ & meter \\
\hline $\mathrm{m}^{2}$ & square meters \\
\hline mi & mile \\
\hline $\mathrm{mi}^{2}$ & square mile \\
\hline MSL & mean sea level \\
\hline PCG & preconditioned conjugate gradient \\
\hline RSS & residual sum of squares \\
\hline SIP & strongly implicit procedure \\
\hline SOWP & site observational work plan \\
\hline SSOR & slice-successive over-relaxation \\
\hline TAC & Technical Assistance Contractor \\
\hline UMTRA & Uranium Mill Tailings Remedial Action \\
\hline
\end{tabular}




\subsection{INTRODUCTION}

\subsection{BACKGROUND}

The Technical Assistance Contractor (TAC) performs the investigations and analysis for the U.S. Department of Energy (DOE) Uranium Mill Tailings Remedial Action (UMTRA) Project. This work was done under the UMTRA Ground Water Project to assist in selection of remediation alternatives. Sources of data included DOE $(1985,1994)$ as well as other (McLean and Johnson, 1987) analyses.

\subsection{MODELING OBJECTIVES}

The objective of this modeling analysis was to develop a two-dimensional, steady-state ground-water flow model for the area near the Shiprock, New Mexico, UMTRA Project site to test the current conceptual understanding of the ground water flow system. Data gaps and conceptual uncertainties were to be identified during model calibration to guide additional data collection activities and development of the site observational work plan (SOWP) (DOE, 1994a).

The technical approach for this analysis consisted of five phases: 1) review of available information on hydrogeologic conditions (performed as part of the SOWP); 2) development of the conceptual model (also part of the SOWPI; 3) model construction, including the design of a finite-difference grid, selection of appropriate boundary conditions, and calibration targets; 4) model calibration; and 5) interpretation of results. 


\subsection{CONCEPTUAL MODEL}

A conceptual model is a concise description of the components of the ground water flow system and is developed from regional, local, and site-specific data. A conceptual model is a precursor to the mathematical model and identifies ground water sources and sinks, the geologic configuration of the aquifers, aquifer properties, and general flow directions. The conceptual model guides the model construction and calibration process and helps interpret the model results by presenting a general understanding of the aquifer system. The SOWP (DOE, 1994a) presents the detailed current conceptual model, and consequently only a brief description of the conceptual model is presented here.

The site is located on the Navajo Indian Reservation, 1 mile (mi) (1.6 kilometers [km]) south of the town of Shiprock, in San Juan County in northwest New Mexico. The site is situated on the southwest bank of the San Juan River (Figure 2.1).

\subsection{STRATIGRAPHY}

The Shiprock site consists of two distinct, interconnected hydrogeologic systems: the alluvial floodplain of the San Juan River and the terrace above it to the west. The terrace is capped by Quaternary age alluvial deposits ranging in thickness from 10 to 45 feet ( $\mathrm{ft}$ ) ( 3 to 13 meters $[\mathrm{ml})$. The terrace deposits unconformably overly the Mancos Shale. Underlying the Mancos Shale are the Cretaceous age Dakota Sandstone and the Jurassic age Morrison Formation.

The floodplain deposits consist of unconsolidated material ranging in size from coarse gravel and cobbles found in high-energy channels to silt and clay found in overbank and backwater deposits. Finer deposits exist in the upper part of the alluvium and thicken away from the escarpment and over structural highs. Figure 2.2, an aerial photograph taken during active milling operations, shows that several channels were present across the northern half of the floodplain. These channels were likely the result of recent flood stage conditions. Deposition from these channels could account for the apparent thickening of the fine-grained upper unit across the northern half of the floodplain.

The Mancos Shale underlies the floodplain alluvium at an average depth of approximately $15 \mathrm{ft}(5 \mathrm{~m})$. The Mancos Shale in the vicinity of the Shiprock site typically consists of flat-lying shales and sandy shales, and is about $1000 \mathrm{ft}$ $(300 \mathrm{~m})$ thick (McLean and Johnson, 1987). The floodplain deposits are bounded on the west and south by the 50-ft (15-m) high Mancos Shale escarpment and along the east by the San Juan River. Figure 2.3 shows the elevation of the top of the Mancos Shale under the floodplain deposits. The Mancos Shale surface is characterized by parallel meander scars (scour channels) caused by ancient erosion of the San Juan River. These scour channels, particularly in the northern part of the floodplain, are below the level of the San Juan River. 

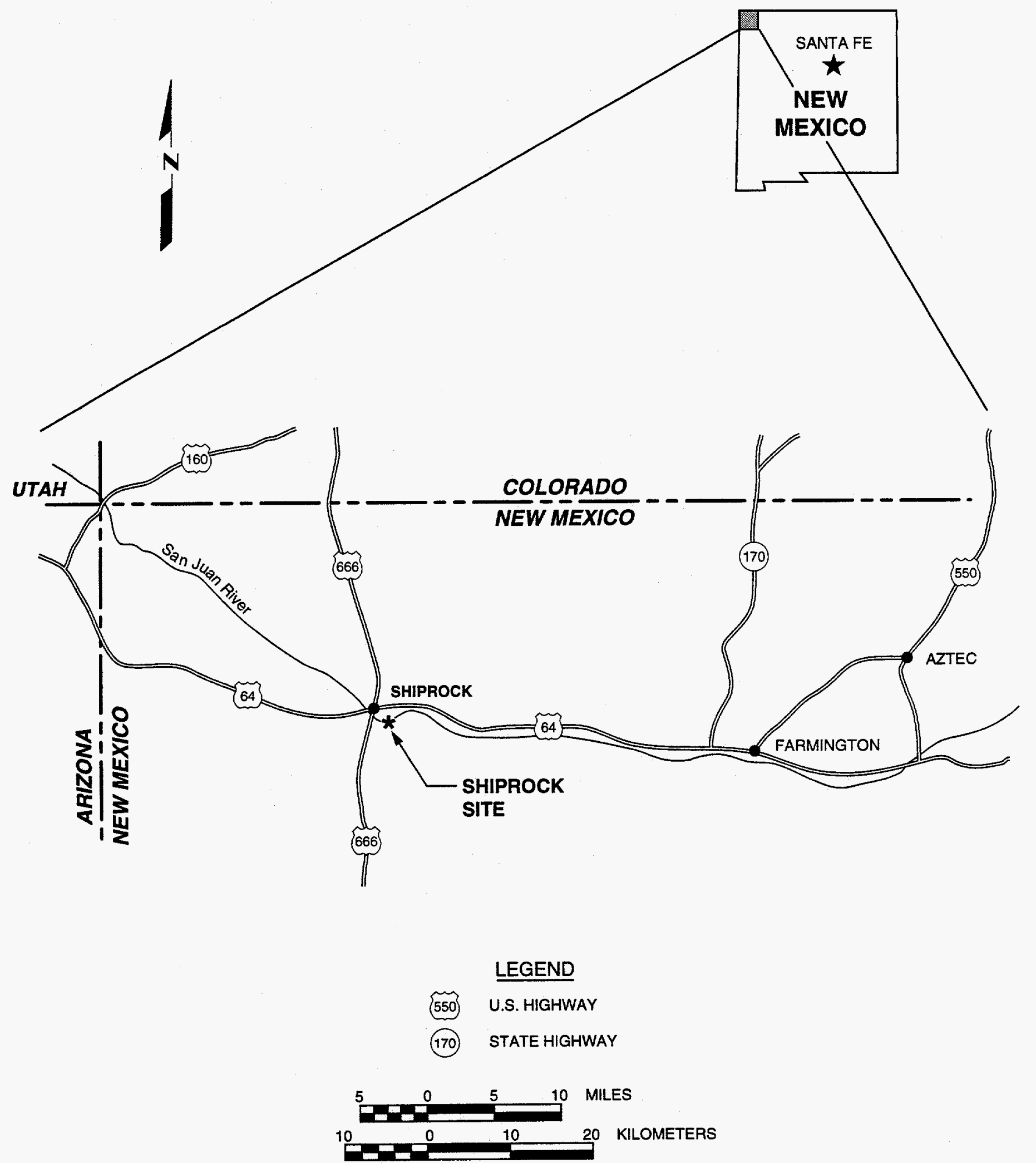

FIGURE 2.1

SHIPROCK SITE LOCATION MAP

SHIPROCK, NEW MEXICO 


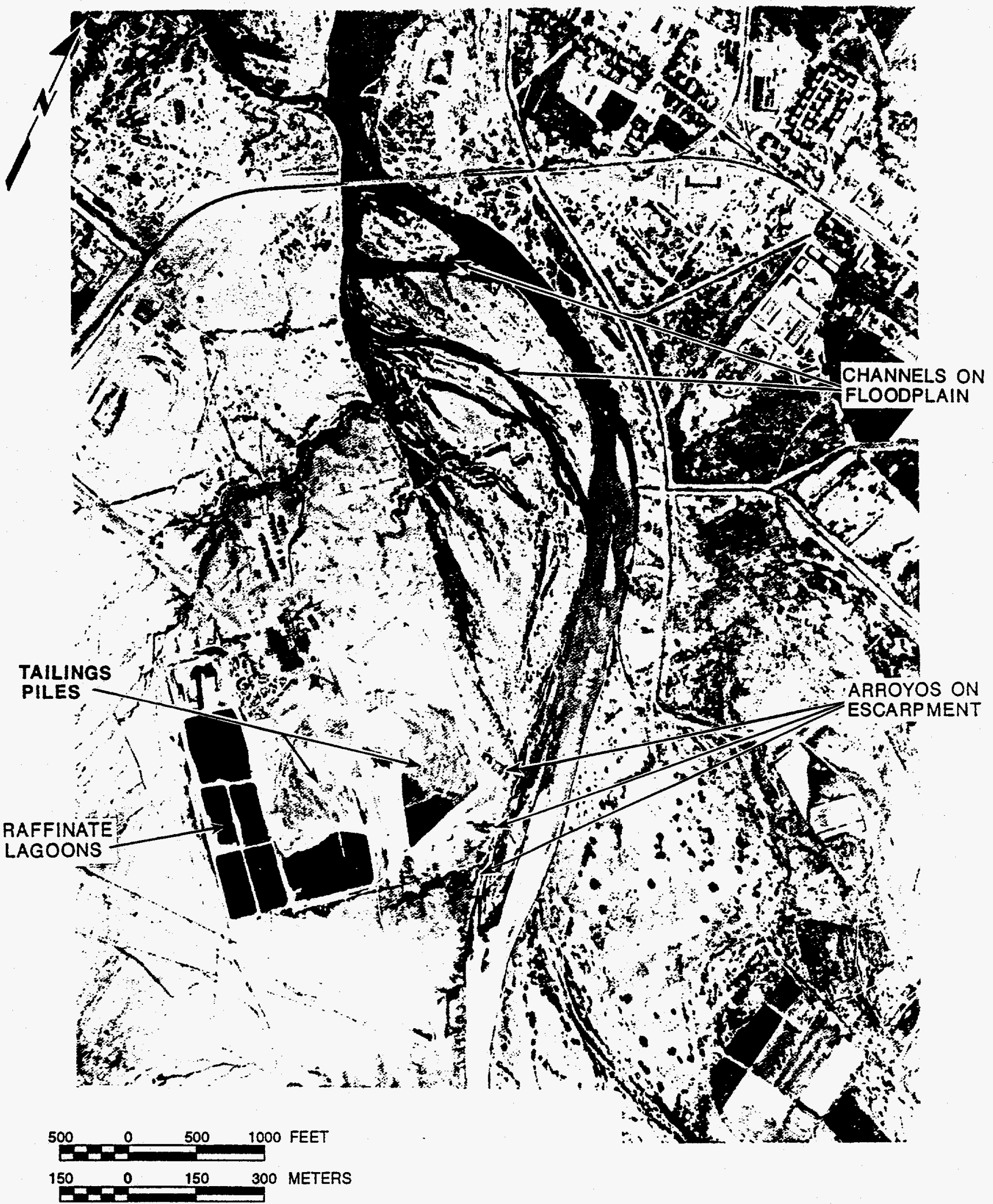

FIGURE 2.2

AERIAL VIEW OF SHIPROCK SITE IN OPERATING PERIOD SHIPROCK, NEW MEXICO, SITE 


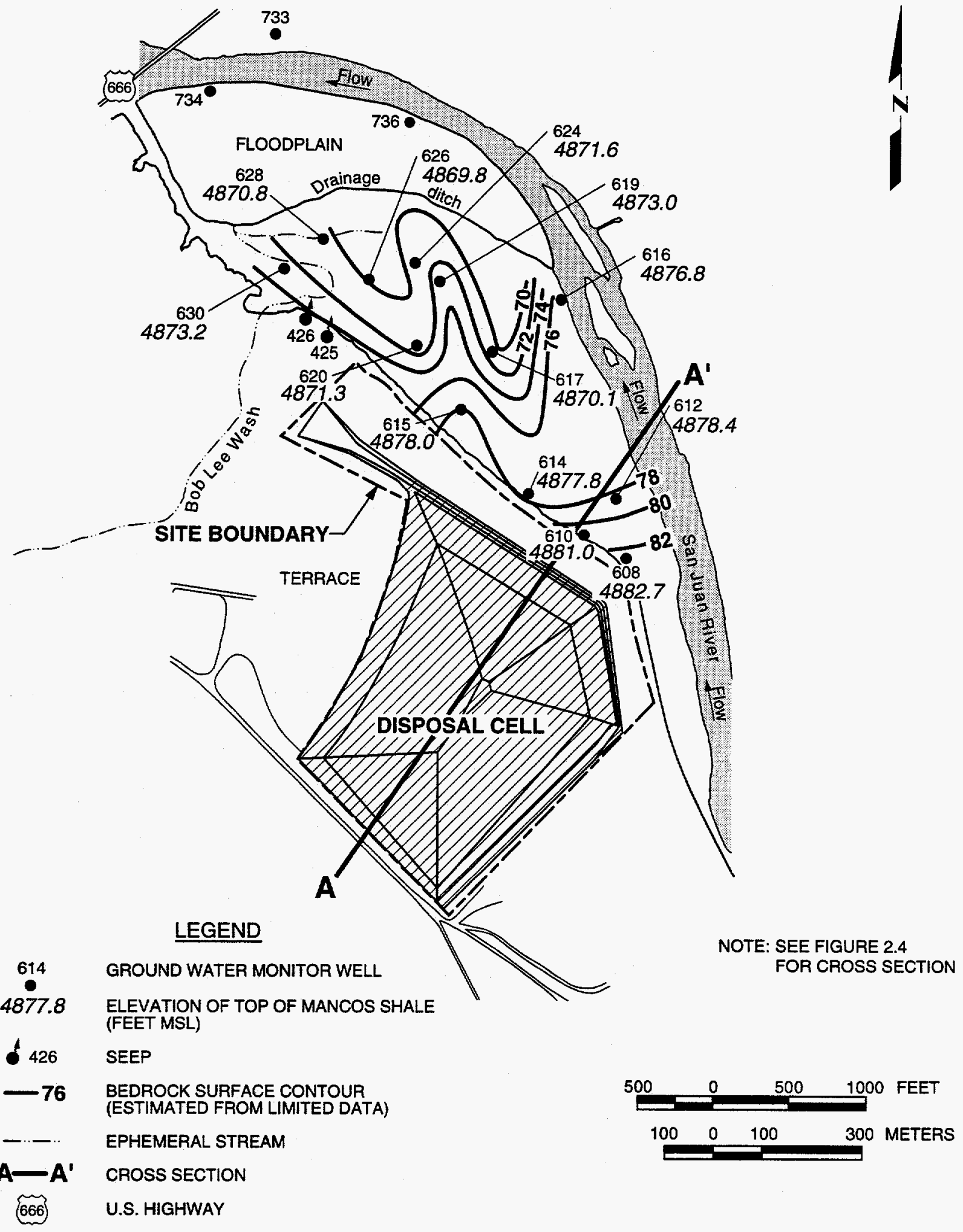

FIGURE 2.3

TOP OF MANCOS SHALE ON FLOODPLAIN SHIPROCK, NEW MEXICO, SITE 


\subsection{HYDRAULIC PROPERTIES}

No aquifer test data exists for the Shiprock site. Aquifer properties were estimated by inspection and comparison with typical ranges described in the literature (DOE, 1994b). Hydraulic conductivity of the floodplain sediments could vary by an order of magnitude (Domenico and Schwartz, 1990), from less than 5 feet per day (ft/day) $(0.001$ centimeters per second $[\mathrm{cm} / \mathrm{s}])$ to more than $300 \mathrm{ft} /$ day $(0.1 \mathrm{~cm} / \mathrm{s})$. An intermediate value of $35 \mathrm{ft} /$ day $(0.012 \mathrm{~cm} / \mathrm{s})$ was used in this analysis.

The upper 10 to $30 \mathrm{ft}(3$ to $10 \mathrm{~m})$ of the Mancos Shale is highly weathered, exhibiting fracture sets, fissility, and low strength. Below this weathered zone the shale is more compact and relatively impermeable. Due to the contrast in hydraulic conductivity, the Mancos Shale is assumed to be the impermeable base of the flow system. However, some leakage may be occurring from the Mancos Shale as a result of milling water left over from plant operations slowly draining down the escarpment.

\subsection{SOURCES AND SINKS}

Ground water in the terrace system occurs in the terrace alluvium and in the upper, weathered part of the Mancos Shale. Some of the water in the Mancos Shale moves along fractures and bedding planes and can be seen seeping from the shale along the escarpment face immediately north of the disposal cell. It is believed that there is another component of flow that enters the Mancos Shale on the terrace, flows towards the San Juan River, and then discharges into the floodplain alluvium (Figure 2.4). Supporting evidence for this has been observed in floodplain monitor wells completed in the Mancos Shale, which have a higher potential than those in the alluvium. Some ground water may also occur in fractures or sandstone stringers in the unweathered Mancos Shale, but occurrence and extent of any such ground water has not been determined.

An artesian well near the site is reportedly completed in the Morrison Formation. This artesian well discharges into Bob Lee Wash about $0.5 \mathrm{mi}(0.8 \mathrm{~km})$ from the floodplain. Water from this well infiltrates onto the floodplain as can be seen by a slight ground water mound, the wetlands, and lower constituent concentrations at the mouth of Bob Lee Wash.

The floodplain alluvium is recharged primarily by water from the San Juan River that enters the floodplain at its upstream end (Figure 2.4). The primary discharge area is along the downstream part of the floodplain where ground water exits back into the San Juan River. Topography and observed water levels on the other side of the San Juan River indicate that there is little underflow and the river is the ground water discharge point in the area. Under these conditions ground water contamination will not migrate beneath the San Juan River unless significant pumping is introduced on the other side of the river (which has not occurred to date). 


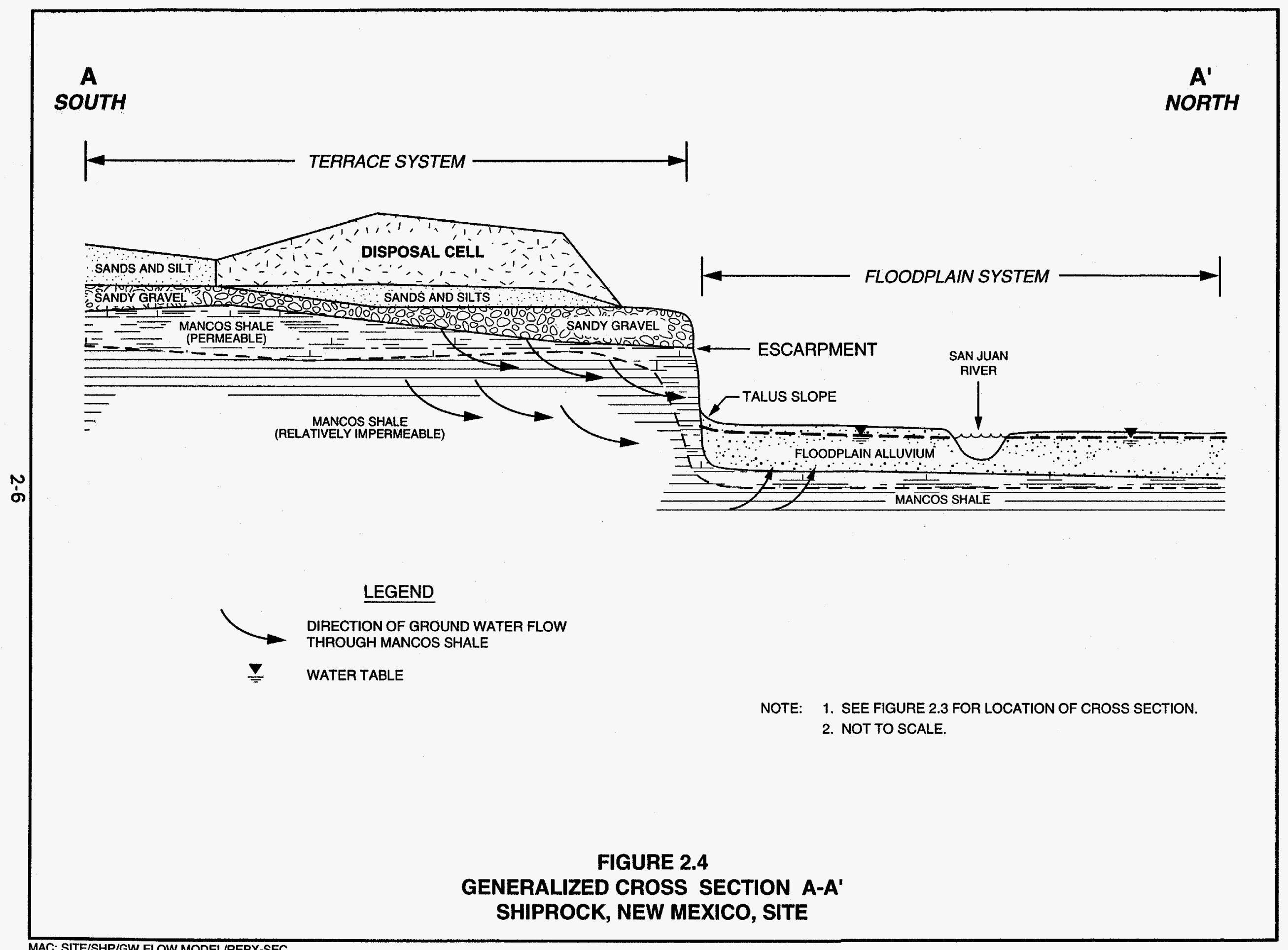


A drainage ditch separates the northwestern third of the floodplain from the rest of the impacted floodplain. This ditch follows an existing meander channel in the floodplain, but appears to have been artificially deepened. During periods of high water the water table intersects this ditch. Ground water flow is diverted into the ditch to discharge into the San Juan River at the extreme northwestern end of the floodplain.

\subsection{GROUND WATER FLOW DIRECTIONS}

Ground water flow is predominantly from the southeast to the northwest (Figure 2.5), reflecting ground water recharge by the San Juan River at the upstream end of the floodplain and ground water discharge into the river at the northwestern end of the floodplain. Some mounding apparently occurs near the mouth of Bob Lee Wash as a result of water infiltration from the artesian well on the terrace. Ground water flow directions in this area have a slight eastward component. Some distortion of the flow field also occurs near monitor well 614 , which may be due to seepage from the escarpment. 


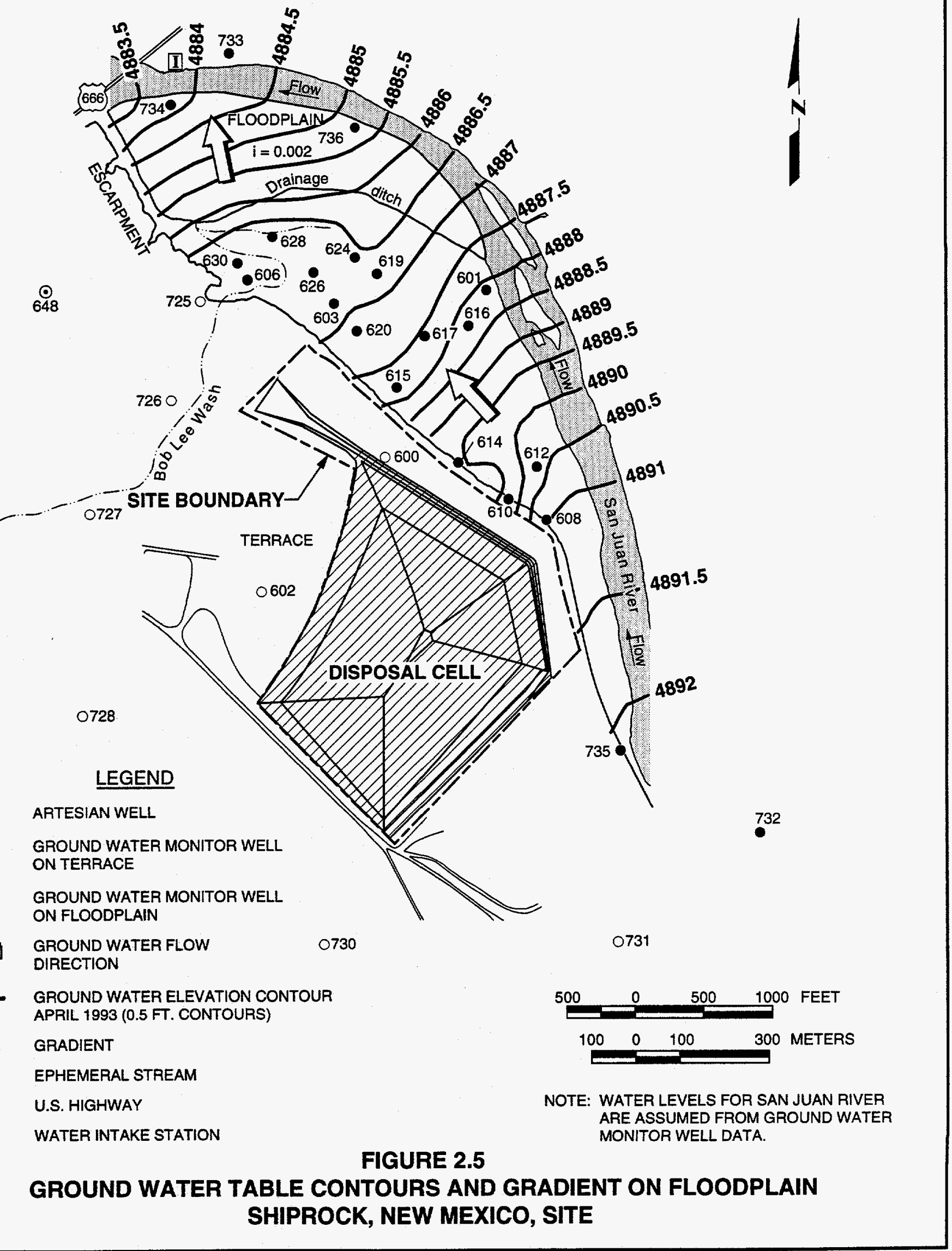




\subsection{GROUND WATER FLOW MODEL CONSTRUCTION}

\subsection{CODE SELECTION}

Simulation of ground water flow at the site was performed with the finitedifference ground water flow code MODFLOW (McDonald and Harbaugh, 1988). MODFLOW is capable of simulating transient or steady-state saturated ground water flow in one, two, or three dimensions. A number of different boundary conditions are available, including specified head, areal recharge, injection or extraction wells, evapotranspiration, drains, and streams or rivers. The code simulates ground water flow using a block-centered finite-difference approach. Aquifers can be simulated as unconfined, confined, or a combination of unconfined and confined. The finite-difference equations may be solved with a strongly implicit procedure (SIP), slice-successive over-relaxation (SSOR), or preconditioned conjugate gradient (PCG) method. MODFLOW is the most widely used ground water flow model in the United States (Rumbaugh and Ruskauff, 1993), is in the public domain, and has been extensively tested. For these reasons MODFLOW was selected for the Shiprock site.

\subsection{MODEL DISCRETIZATION}

The finite-difference technique requires that the conceptual model of the aquifer be divided into a set of discrete blocks or cells. These blocks form the model grid. A node is located at the center of each block. The process of dividing the aquifer system into blocks is called discretization. Water levels computed for each block are the average over the volume of the block. Thus, adequate discretization is required to resolve features of interest, and yet not be computationally burdensome. An algebraic equation that describes ground water flow is written for each block in terms of the surrounding blocks. The complete set of linear equations is iteratively solved until the change between iterations meets a criterion set by the analyst. Numerical models are superior to analytic approaches in that each block can be assigned a different set of properties, which allows incorporation of spatially varying parameters such as thickness and hydraulic conductivity.

The two-dimensional model covers approximately 0.6 square mile $\left(\mathrm{mi}^{2}\right)$ $\left(1.5\right.$ square kilometers $\left.\left[\mathrm{km}^{2}\right]\right)$, and extends to a depth of about $30 \mathrm{ft}(9 \mathrm{~m})$ below land surface. The active model domain is about $3500 \mathrm{ft}(1066 \mathrm{~m})$ in the east-west direction and about $4000 \mathrm{ft}(1219 \mathrm{~m})$ in the north-south direction. A finite-difference grid composed of 45 columns, 97 rows, and 1 layer was used to simulate the aquifer system for a total of 4365 nodes. Figure 3.1 shows the model grid and boundary conditions.

A uniform grid spacing of $50 \mathrm{ft}(15 \mathrm{~m})$ between columns (x-direction) and between rows (y-direction) was used. The grid was designed so that boundary conditions would correspond with physical or hydrologic boundaries. 

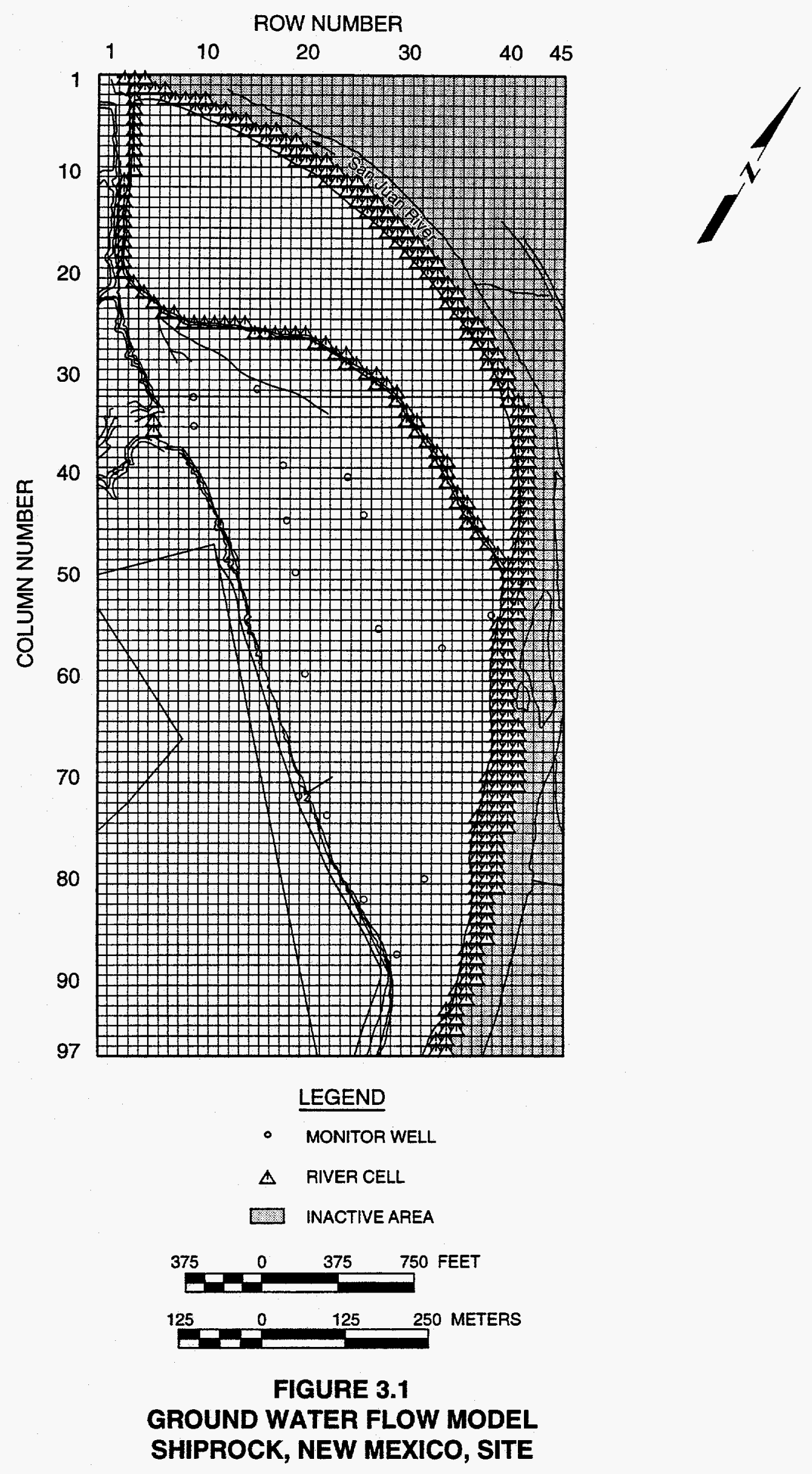
In the finite-difference method the grid should be oriented in the main direction of ground water flow for best accuracy. Thus, the grid was rotated 30 degrees counterclockwise from true north for the Shiprock site.

The bottom of the model was assumed to be the upper surface of the Mancos Shale. As discussed in Section 2.1, a map of the elevation of the top of the Mancos Shale was developed and used as input for the bottom of the model. No data exists for the elevation of the top of Mancos Shale north of the drainage ditch. Consequently, a uniform value of $4870 \mathrm{ft}(1484 \mathrm{~m})$ above mean sea level (MSL) was used in this area.

\subsection{BOUNDARY CONDITIONS}

Once the area of interest has been discretized, it is assumed that the surrounding area can be ignored. The model, however, must account for the effects of outside conditions that may affect the model domain and allow water to flow in and out. These effects are accounted for by the use of boundary conditions, which make it possible to isolate a specific area for study. External model boundaries were chosen to correspond to natural hydrologic boundaries of the ground water flow system.

The specified rate, or flux, condition allows a given quantity of water to be applied from a unit area of the model per unit time. The specified rate condition is used to represent both precipitation recharge and wells. The recharge package in MODFLOW was used to represent possible rainfall recharge and leakage from the underlying Mancos Shale. Because the model is two-dimensional, these two components are lumped together. The specified rate condition may also be used to simulate no-flow boundaries by specifying the rate as zero. The escarpment west of the floodplain, the model domain east of the centerline of the San Juan River, and portions of the southern boundary were simulated as no-flow boundaries.

An artesian well on the plateau above the escarpment taps the bedrock and flows about 60 gallons per minute (gpm) (227 liters per minute [L/min]) (DOE, 1994a). This flow travels down Bob Lee Wash, and some portion ultimately infiltrates into the alluvium where the wash reaches the floodplain. This conclusion is based on a distinct ground water mound at the mouth of Bob Lee Wash and a corresponding zone of lower constituent concentrations apparently caused by this flow locally flushing the alluvium. Two injection wells at the mouth of Bob Lee Wash were used to represent the net flow to the alluvium.

A river boundary is called a value-dependent flux condition because the rate of ground water entering or exiting the model depends on the head difference between the value computed at the boundary by the model and a source of water maintained at a constant level outside the model. This type of boundary is more flexible than the constant head or constant flux boundaries because both the simulated flow rate and head can vary. River boundaries were assigned along the San Juan River and the drainage ditch. The elevation of the 
San Juan River is not known precisely, but was assumed to be closely related to the observed water table. The elevation of the drainage ditch was estimated from topographic maps.

\subsection{PARAMETER ZONATION}

Simulation of ground water flow requires knowledge of the hydraulic properties of the formations. The areal distribution of hydraulic conductivity and recharge within a layer is required as input to MODFLOW. Model parameters assigned in the MODFLOW code include recharge, horizontal hydraulic conductivity, and bottom elevation. The technique of parameter zonation was used to define the spatial variation of the aquifer parameters. This method requires the delineation of zones, within which a constant value of the parameter is assigned. When possible the zones are chosen based on hydrogeologic information such as the nature and thickness of a formation. In the Shiprock model all parameters had a single uniform value, with the exception of the top elevation of the Mancos Shale.

\subsection{CALIBRATION TARGETS}

Calibration targets are a set of field measured values, typically ground water elevations, to which model predicted values are compared. The goal in selecting calibration targets is to define a set of ground water-level measurements that are reliable and spatially distributed throughout the area. Ground water levels observed in April 1993 were used to calibrate the model. These levels are typical of ground water conditions in the alluvium. Table 3.1 summarizes the data for the 15 wells used to calibrate the model. 
Table 3.1 Calibration target locations and values, Shiprock, New Mexico, site

\begin{tabular}{cccc}
\hline Well identification & Row & Column & $\begin{array}{c}\text { Water level } \\
\text { (ft above MSL) }\end{array}$ \\
\hline 608 & 88.87 & 30.21 & 4892.740 \\
610 & 80.74 & 26.17 & 4893.950 \\
612 & 77.81 & 33.06 & 4892.900 \\
614 & 71.78 & 22.50 & 4891.830 \\
615 & 58.25 & 21.29 & 4890.960 \\
616 & 54.87 & 34.18 & 4890.780 \\
617 & 53.35 & 28.63 & 4890.350 \\
619 & 43.10 & 26.21 & 4891.020 \\
620 & 47.79 & 19.86 & 4888.360 \\
624 & 40.31 & 24.37 & 4889.600 \\
626 & 38.47 & 18.24 & 4888.760 \\
628 & 31.96 & 15.27 & 4888.370 \\
630 & 32.20 & 8.79 & 4886.240 \\
736 & 18.07 & 26.55 & 4885.300 \\
734 & 4.33 & 6.77 & 4883.700 \\
\hline & & & \\
\hline
\end{tabular}




\subsection{GROUND WATER FLOW MODEL CALIBRATION}

Two approaches are typically used to calibrate models: trial-and-error or automated inverse procedures. The trial-and-error approach is tedious and often subject to the analyst's biases (Anderson and Woessner, 1992). The inverse procedure approach is similar to the trial-and-error approach in that a large number of simulations are run to determine parameter sensitivity. However, the inverse procedure checks the computed ground water levels and adjusts parameters in a systematic fashion to minimize the deviation between observed and computed ground water levels. The advantage to using an automated calibration technique is that it provides a structured, systematic approach to the calibration process (Anderson and Woessner, 1992). These procedures greatly reduce the time required for model calibration and generally provide a better overall calibration.

\subsection{PARAMETER ESTIMATION TECHNIQUE}

A numerical groundwater flow model is calibrated by varying the model parameters (hydraulic properties or boundary conditions) to obtain the best match between the observed and simulated ground water levels. Ground water velocity must also be considered in model calibration, because it is possible to have a good calibration statistically and not have the correct velocities and flow directions (Duffield et al., 1990). Successfully calibrating a flow model to observed water levels, velocities, and flow directions allows the model to be used to predict ground water travel times and flow paths.

Konikow (1978) and Anderson and Woessner (1992) indicate that a ground water flow model should be calibrated to point data (as performed in this analysis) to eliminate any interpretive bias that may be introduced when attempting to match a contoured water-table surface. Only discrete measurement points should be used to produce answers free of contouring interpretations and other artifacts. In addition, the number of parameters used to calibrate the model should be minimized to ensure model uniqueness. This approach is known as parameter parsimony. These techniques were used to calibrate the Shiprock model.

An inverse procedure for parameter estimation was used to calibrate the Shiprock flow model. The general algorithm applied in conjunction with the MODFLOWP code is known as the Gauss-Newton method and is described in greater detail by Hill (1992).

Model calibration is judged in this analysis by quantitatively analyzing model residuals and qualitative inspection of flow directions. A residual is defined here as the difference between the observed and model calculated water levels. The residual mean and standard deviation are the quantitative criteria by which model calibration was judged. The mean residual is the arithmetic average of all the differences between observed and predicted water levels. A positive residual indicates that the model has computed ground water levels less than the observed measurement (underprediction); a negative residual indicates the 
model has computed ground water levels greater than the observed measurement (overprediction). For a statistically acceptable calibration, the residuals and the statistics based upon the residuals should be close to zero. It is possible, however, to have an acceptable mean residual and still have considerable errors in the model (i.e., errors of +50 and -50 added together give the same mean residual as errors of +1 and -1 added together). Thus an additional measure, the residual standard deviation, is used to quantify how well the model fits reality. The residual standard deviation quantifies the spread of the differences between observed and computed levels. Finally, the residual sum of squares is used to judge goodness of global fit.

\subsection{CALIBRATION RESULTS}

Because of limited data, the model calibration exercise resembled a general sensitivity analysis. After the initial model construction, the simulation was run to check for overall correctness of the flow field. A bias towards

underprediction occurred in the southern half of the model, with simulated water levels being systematically 2 to $4 \mathrm{ft}(0.6$ to $1.2 \mathrm{~m})$ too low. The stage of the San Juan River in the southern third of the domain was increased 0.5 to $1 \mathrm{ft}$ $(0.15$ to $0.3 \mathrm{~m})$ to compensate. Simulated ground water levels were still somewhat low in the area, however at this phase of the analysis further increase in stage was not felt to be warranted.

The next phase of the analysis consisted of varying the inflow rate from Bob Lee Wash and determining what hydraulic conductivity was required for a reasonable calibration. Figure 4.1 shows a plot of infiltration rate versus the multiplier for the base value ( $35 \mathrm{ft} / \mathrm{day})$. The inverse algorithm was allowed 10 iterations to attempt to improve the calibration. The multiplier shown was the one that occurred when rate of change in the objective function (residual sum of squares) became small. At infiltration rates greater than $40 \mathrm{gpm}(152 \mathrm{~L} / \mathrm{min})$, the rate of change in hydraulic conductivity becomes relatively small. This analysis shows a direct dependence of aquifer hydraulic conductivity on flow from Bob Lee Wash and how lack of constraining data makes discrimination of correct parameters difficult.

After performing the sensitivity analysis on the effects of Bob Lee Wash infiltration, the model sensitivity to both Bob Lee Wash inflow and recharge (leakage from the Mancos Shale combined with precipitation recharge) was investigated. The initial parameters in this analysis were $35 \mathrm{ft} / \mathrm{day}(0.012 \mathrm{~cm} / \mathrm{s})$ of hydraulic conductivity, 0.5 inches $(1.27 \mathrm{~cm})$ per year of recharge, and $60 \mathrm{gpm}(228 \mathrm{~L} / \mathrm{min})$ of wash inflow. The inverse algorithm was given 15 iterations to attempt to improve the calibration by simultaneously adjusting wash inflow and recharge. Figure 4.2 shows model residual sum of squares (RSS) as a function of wash inflow and recharge. Note that the objective function improves as wash inflow decreases and recharge increases simultaneously. This improvement is because the local disruption of the model calibration at the mouth of the wash from inflow diminishes as the flow rate 


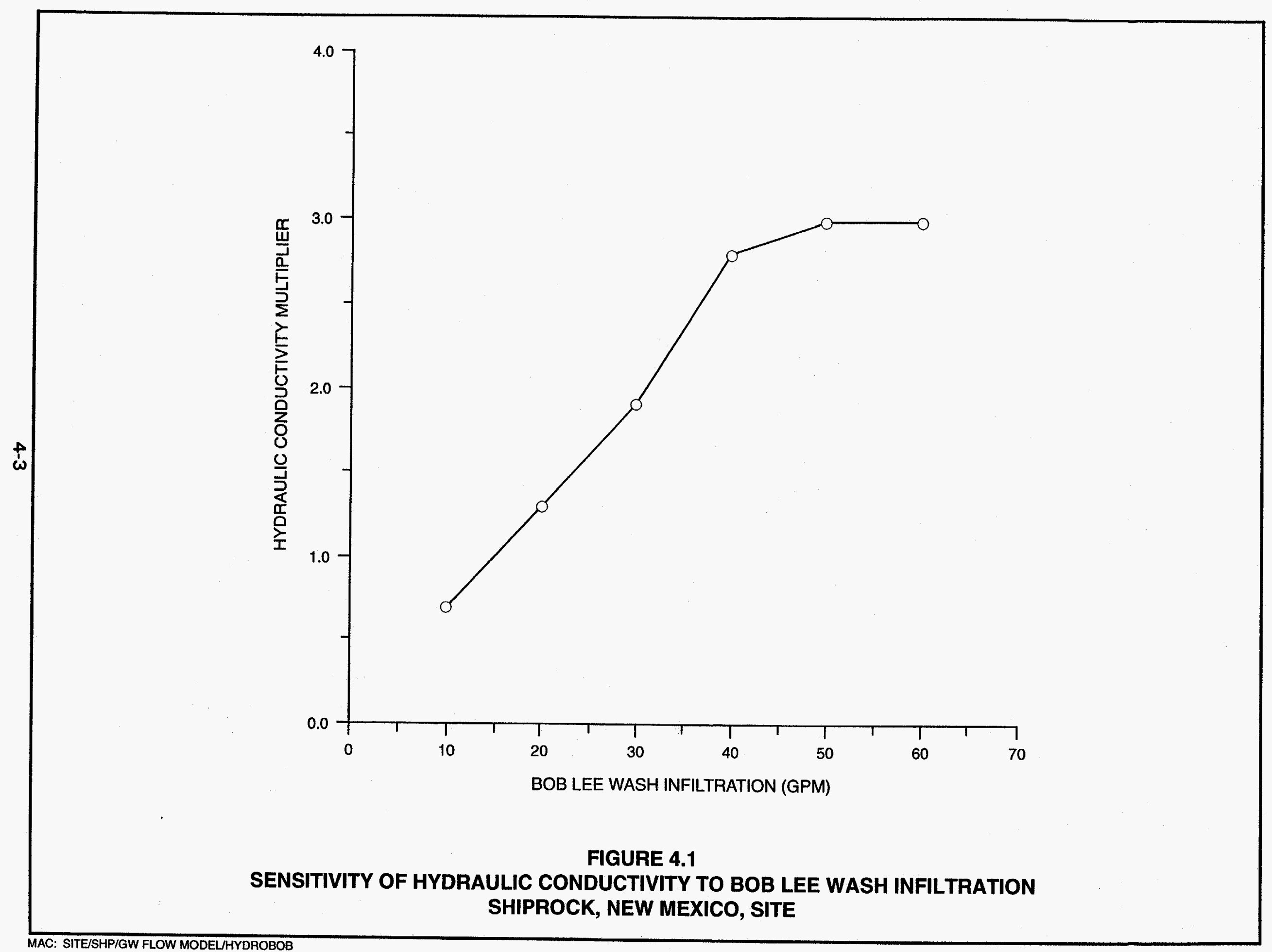




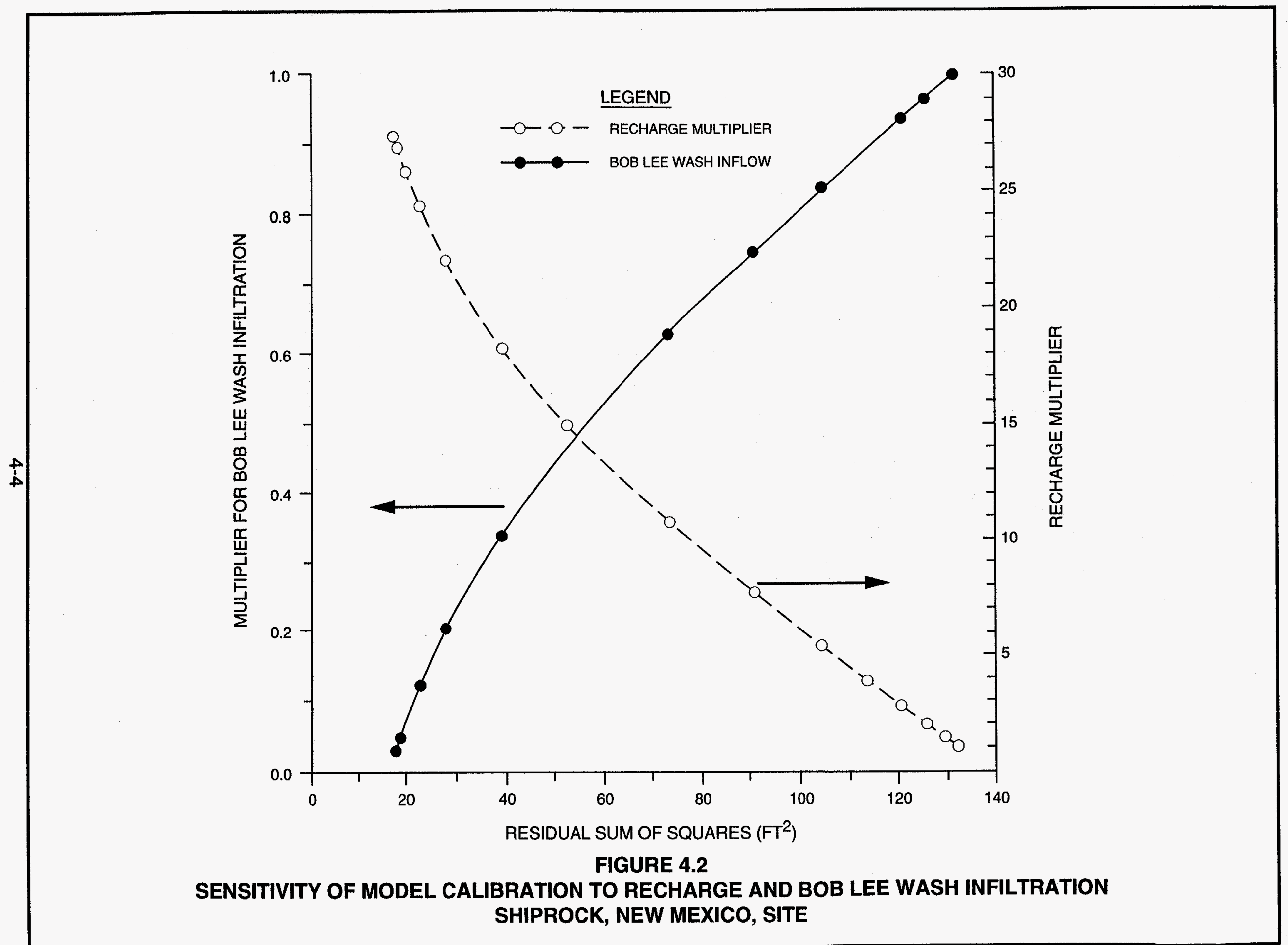


decreases and model calibration improves to the south (which has had consistently underpredicted water levels) as recharge increases.

An important part of model calibration is inspecting the simulated flow directions and ground water gradients; it is possible to have a statistically good match with an incorrect flow field. The flow field from the ninth estimate (one of the statistically better fits) (see Figure 4.2) was plotted with the residuals as shown in Figure 4.3. While this set of parameter estimates produced a good overall statistical fit, the overall ground water flow field does not match that interpreted for the floodplain. In particular, there is a strong easterly component to the model-simulated ground water flow field that is not believed to exist at the Shiprock site. There is still a consistent underprediction of water levels along the southern part of the domain. Inspection of the residuals suggests that the overall driving mechanism for these results was the fact that simulated ground water levels were systematically to low in the southern part of the model.

At this point in the model calibration the San Juan River stage along the southern third of the model domain was adjusted again to investigate what changes would be necessary to produce the best model fit. Another $2 \mathrm{ft}$ $(0.6 \mathrm{~m})$ was added to the southern quarter of the river and another $1 \mathrm{ft}(0.3 \mathrm{~m})$ was added as far north as the islands to create the final model configuration. Thus, stages were adjusted as much as $3 \mathrm{ft}(1 \mathrm{~m})$ in the southern part of the model over the original estimates. The effects of this change plus 2 inches $(5 \mathrm{~cm})$ per year of recharge are shown in Figure 4.4.

A plot of the observed versus simulated water levels for the model described in the previous paragraph is shown in Figure 4.5. If the observed and simulated water levels matched exactly (i.e., perfect calibration), the residuals would fall on a straight line with a slope of $\mathbf{4 5}$ degrees. In a real-world calibration, however, there will be some scatter of residuals about this line of perfect match, and this is the case with the Shiprock model. The largest error was at monitor well 619 , with a deviation of $2.8 \mathrm{ft}(0.84 \mathrm{~m})$ between the observed and computed values. There is some bias towards underprediction in the residuals, as can be seen from the general grouping of levels below the line of perfect calibration.

The quantitative criteria for judging model calibration are the residual mean and residual standard deviation, as discussed in Section 4.1. Table 4.1 presents a comparison of observed and simulated water levels. Table 4.2 presents the calibration summary statistics. The residual mean is $0.73 \mathrm{ft}(0.22 \mathrm{~m})$ and indicates an average underprediction of ground water levels. The residual standard deviation is $1.24 \mathrm{ft}(0.37 \mathrm{~m})$ and the residual sum of squares is 31 square feet $\left(\mathrm{ft}^{2}\right)\left(9.3\right.$ square meters $\left.\left[\mathrm{m}^{2}\right]\right)$. 


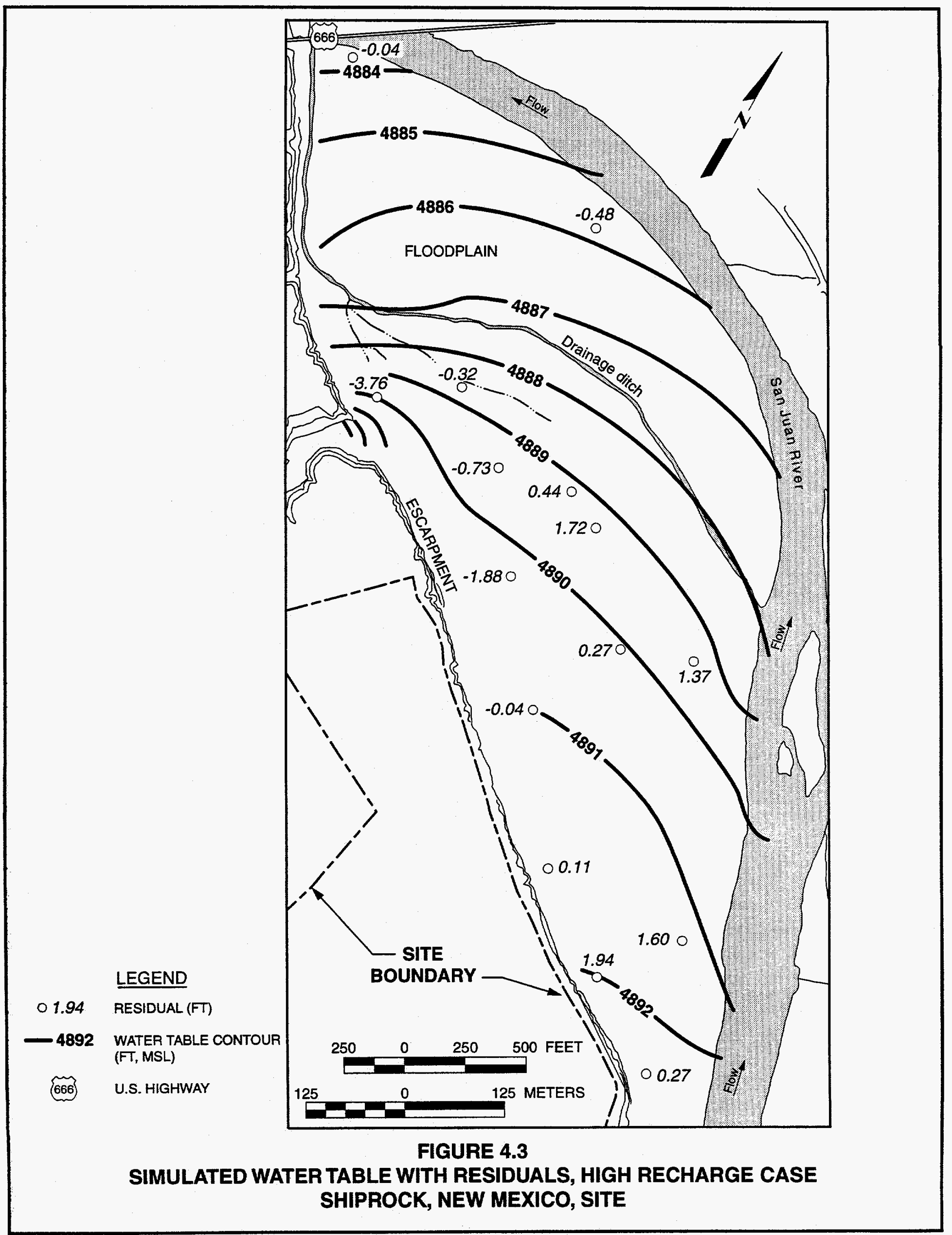




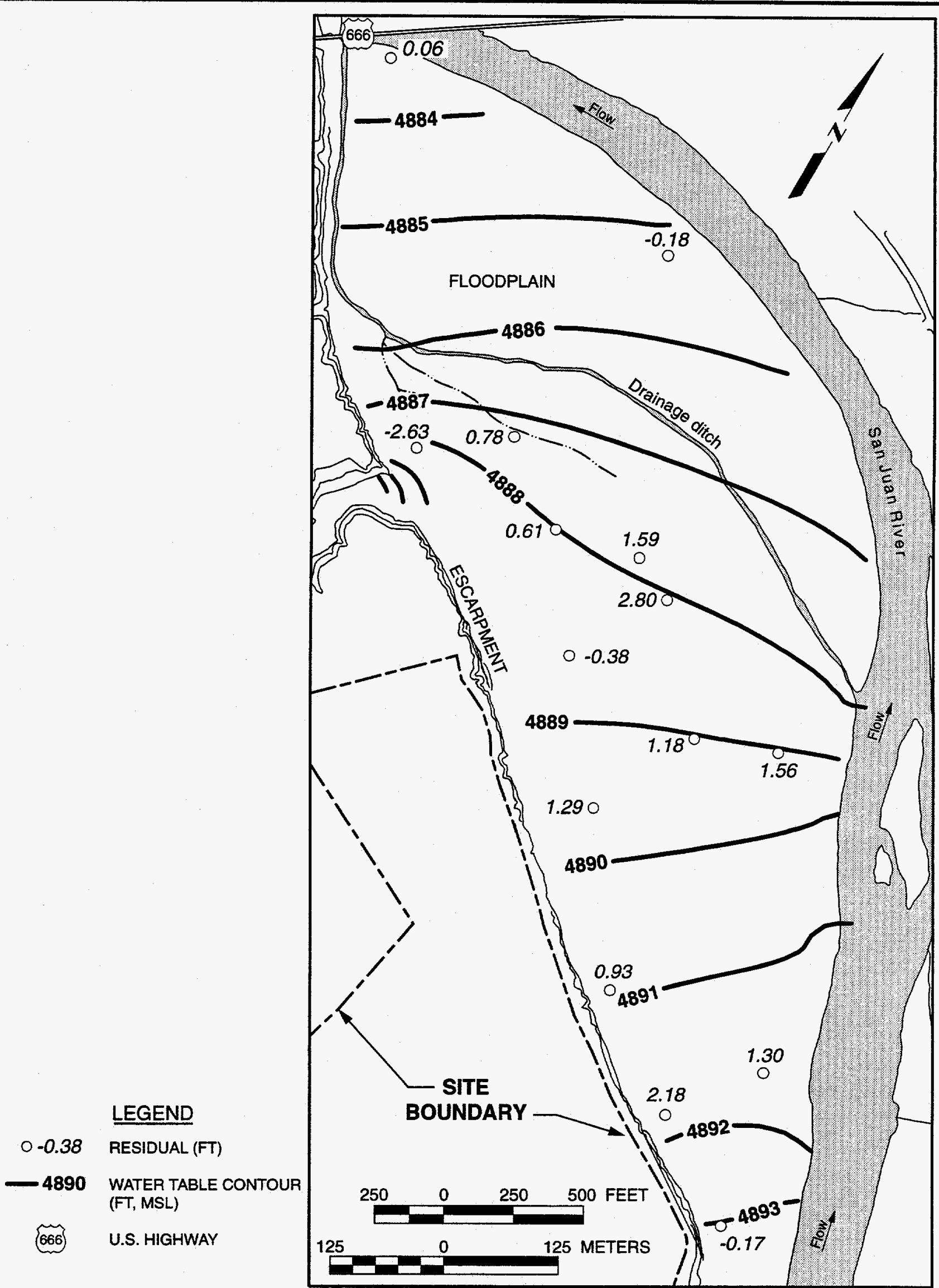

FIGURE 4.4

SIMULATED WATER TABLE WITH RESIDUALS, INCREASED RIVER STAGE, LOW RECHARGE SHIPROCK, NEW MEXICO, SITE 


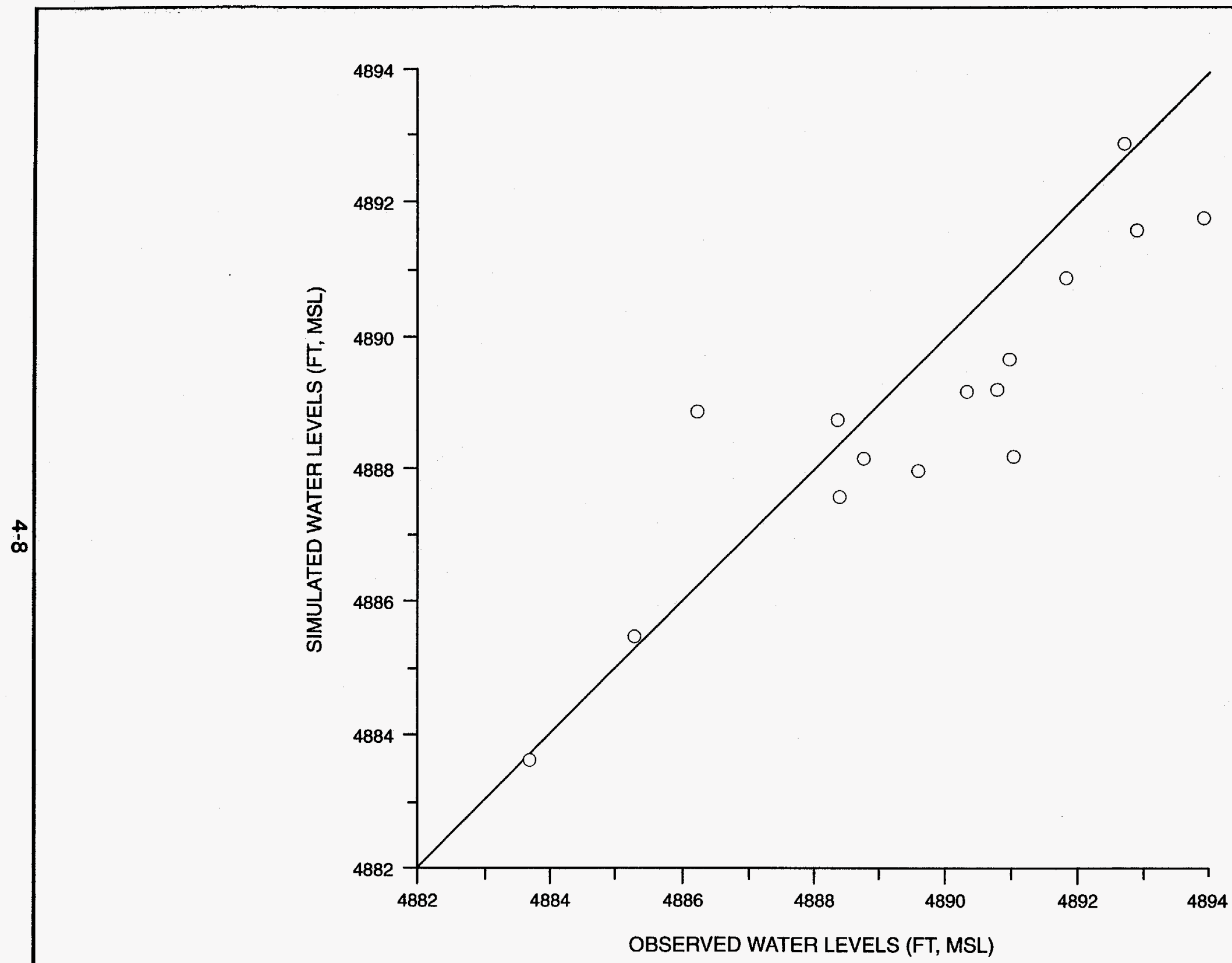

FIGURE 4.5

OBSERVED VERSUS SIMULATED WATER LEVELS SHIPROCK, NEW MEXICO, SITE

MAC: SITE/SHP/GW FLOW MODELSIMWATER 
Table 4.1 Observed versus calculated water levels, Shiprock, New Mexico, site

\begin{tabular}{|c|c|c|c|c|c|c|}
\hline \multirow{2}{*}{$\begin{array}{c}\text { Well } \\
\text { identification }\end{array}$} & \multicolumn{2}{|c|}{ Target head } & \multicolumn{2}{|c|}{ Model head } & \multicolumn{2}{|c|}{ Residual } \\
\hline & (ft) & $(\mathrm{m})$ & (ft) & (m) & (ft) & (m) \\
\hline 608 & 4892.74 & 1491.31 & 4892.91 & 1491.36 & -0.17 & -0.052 \\
\hline 610 & 4893.95 & 1491.67 & 4891.77 & 1491.01 & 2.18 & 0.66 \\
\hline 612 & 4892.90 & 1491.36 & 4891.60 & 1490.96 & 1.30 & 0.39 \\
\hline 614 & 4891.83 & 1491.03 & 4890.90 & 1490.75 & 0.93 & 0.28 \\
\hline 615 & 4890.96 & 1490.76 & 4889.67 & 1490.37 & 1.29 & 0.39 \\
\hline 616 & 4890.78 & 1490.71 & 4889.22 & 1490.23 & 1.56 & 0.47 \\
\hline 617 & 4890.35 & 1490.58 & 4889.17 & 1490.22 & 1.18 & 0.36 \\
\hline 619 & 4891.02 & 1490.78 & 4888.22 & 1489.93 & 2.80 & 0.85 \\
\hline 620 & 4888.36 & 1489.97 & 4888.74 & 1490.09 & -0.38 & -0.11 \\
\hline 624 & 4889.60 & 1490.35 & 4888.01 & 1489.86 & 1.59 & 0.48 \\
\hline 626 & 4888.76 & 1490.10 & 4888.15 & 1489.91 & 0.61 & 0.18 \\
\hline 628 & 4888.37 & 1489.97 & 4887.59 & 1489.74 & 0.78 & 0.24 \\
\hline 630 & 4886.24 & 1489.32 & 4888.87 & 1490.13 & -2.63 & -0.80 \\
\hline 736 & 4885.30 & 1489.04 & 4885.48 & 1489.09 & -0.18 & -0.055 \\
\hline 734 & 4883.70 & 1488.55 & 4883.64 & 1488.53 & 0.06 & 0.018 \\
\hline
\end{tabular}

Table 4.2 Summary calibration statistics, Shiprock, New Mexico, site

\begin{tabular}{ll}
\hline Number of targets & $=15$ \\
Residual mean & $=0.73 \mathrm{ft}(0.22 \mathrm{~m})$ \\
Residual standard deviation & $=1.25 \mathrm{ft}(0.38 \mathrm{~m})$ \\
Residual sum of squares & $=31.3 \mathrm{ft}^{2}\left(2.9 \mathrm{~m}^{2}\right)$ \\
Minimum residual & $=-2.6 \mathrm{ft}(-0.8 \mathrm{~m})$ \\
Maximum residual & $=2.8 \mathrm{ft}(0.85 \mathrm{~m})$ \\
\hline
\end{tabular}




\subsection{GROUND WATER FLOW MODEL ANALYSIS}

\subsection{MODEL WATER BALANCE}

Volumetric water balances are quantitative model estimates of the sources and sinks of water in the aquifer system. A water budget analysis was performed to better understand the movement of water in the aquifer system. The water balance error was within 0.1 percent, and shows that all water was accounted for and that MODFLOW correctly solved the governing flow equations.

Table 5.1 gives the model water balance for the flow field shown in Figure 4.4 (the final model configuration). River leakage accounts for 54 percent of inflow. The remaining inflow is evenly derived from Bob Lee Wash inflow and recharge (precipitation and Mancos Shale leakage). The sole ground water sink in the model is the San Juan River, with all water entering the aquifer discharging back into the river.

Table 5.1 Simulated water balance, Shiprock, New Mexico, site

\begin{tabular}{|c|c|c|c|c|}
\hline \multirow[b]{2}{*}{ Component } & \multicolumn{2}{|c|}{ Inflow } & \multicolumn{2}{|c|}{ Outflow } \\
\hline & (gpm) & (L/min) & (gpm) & $(\mathrm{L} / \mathrm{min})$ \\
\hline Bob Lee Wash inflow & 13.25 & 50.35 & - & - \\
\hline $\begin{array}{l}\text { Recharge } \\
\text { (precipitation and Mancos Shale) }\end{array}$ & 13.27 & 50.43 & - & - \\
\hline San Juan River & 31.20 & 118.56 & 57.22 & 219.34 \\
\hline Totals & 57.72 & 219.34 & 57.72 & 219.34 \\
\hline
\end{tabular}




\subsection{DISCUSSION AND CONCLUSIONS}

In developing the numerical model for the UMTRA Project Shiprock site it became apparent that, other than water level data, very little information existed to constrain the model parameters. Because of the uncertainties arising from this lack of data, the model cannot be considered to be a good predictor of ground water flow conditions. However, the modeling analysis was useful for gaining insight into the dynamics of the aquifer system and identifying data collection tasks.

A model cannot be used for predicting the behavior of an aquifer system unless sitespecific numerical values for aquifer parameters have been determined by field measurements (e.g., pumping tests) (Bear et al., 1992). However, even without such data, important questions about the suitability of the conceptual model can be studied and the behavior of the aquifer with regards to the various conceptual model components can be quantitatively analyzed. For instance, a hydraulic conductivity of $35 \mathrm{ft} /$ day $(0.012 \mathrm{~cm} / \mathrm{s})$ and infiltration from Bob Lee Wash of $60 \mathrm{gpm}(228 \mathrm{~L} / \mathrm{min})$ cannot both occur because the simulated flow field bears little resemblance to actual conditions. The model demonstrates that inflow to the alluvial aquifer from the artesian well draining into Bob Lee Wash has a profound effect on the plausible value of hydraulic conductivity. If the assumed value of $35 \mathrm{ft} /$ day $(0.012 \mathrm{~cm} / \mathrm{s})$ is used, it would not be possible to have the bulk of the aquifer flow come from the river and still be able to reasonably replicate the flow field. Thus, there is an internal inconsistency with the current conceptual model.

The flow model is sensitive to the stage of the San Juan River in the upstream area, which is consistent with the conceptual model in which the bulk of the aquifer inflow occurs along the upstream reach of the floodplain. Since little data exists near the river, the exact degree of contribution is unknown. It may be possible to adjust river stages in the model to reduce or remove the recharge component. However, given the lack of data on river stages, the validity of such adjustment is questionable.

Large of amounts of recharge from precipitation and/or Mancos Shale leakage were found to produce a statistically good model fit. However, the ground water flow directions poorly matched those believed to exist at the site. Thus, large amounts of recharge from Mancos Shale leakage and precipitation are unlikely; although the small amount of recharge applied in the final version of this analysis helped improve model calibration and still resulted in a reasonable flow. With the current information it is not possible to further refine the estimate of water budget components.

As can be seen from this analysis, the linearity of the ground water flow equation makes it possible for compensating errors to exist (transmissivity offset by flow rate) in a steady-state model without changing the head field (deMarsily, 1986). This problem is termed nonuniqueness and is exacerbated if there is no or little information on parameter values and if calibration targets are few or poorly distributed (Anderson and Woessner, 1992).

Information required to alleviate the problem of identifying the correct aquifer model includes additional monitoring wells, particularly near the upstream end of the aquifer close 
to the San Juan River, and the use of flows as calibration targets (e.g., flow from Bob Lee Wash) (Anderson and Woessner, 1992). Nonuniqueness is especially a problem when no transmissivity data exist (Neuman, 1980), and aquifer testing should be performed to assist in refining the conceptual model and selecting the appropriate remedial action.

A successful model application requires appropriate site-specific information. Figure 6.1 illustrates the model application process. Each phase of the process may consist of various steps; often, results from one step are used as feedback in previous steps, resulting in an iterative procedure (Bear et al., 1992). This analysis is preliminary and scoping in nature, and attempted to assess the relative contribution and importance of the various components of the aquifer conceptual model. As can be seen from Figure 6.1, after the model is calibrated it may be determined that more data is needed, which in turn may lead to revision of the conceptual model. 


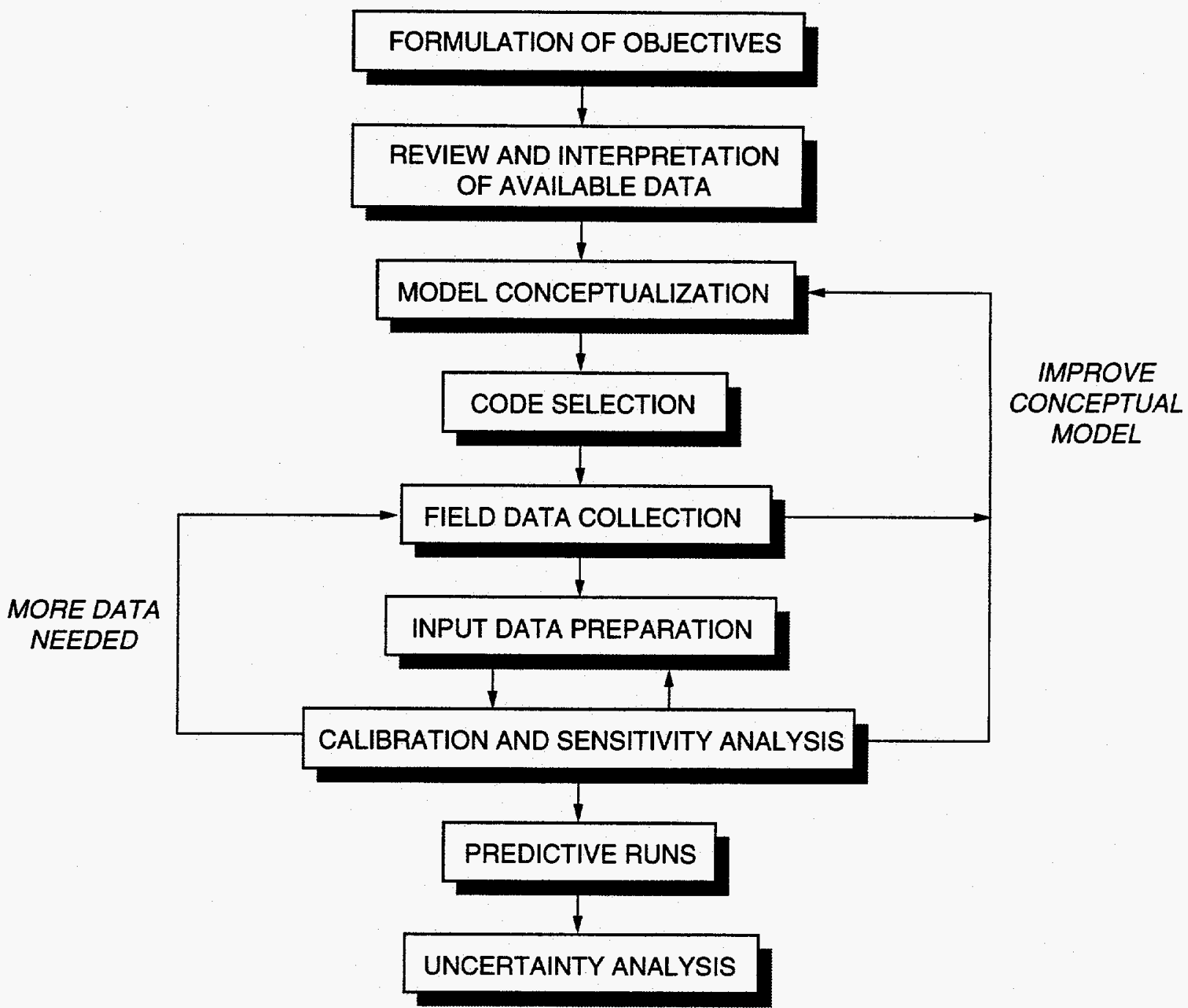

FIGURE 6.1

MODEL APPLICATION PROCESS

SHIPROCK, NEW MEXICO, SITE 


\subsection{LIST OF CONTRIBUTORS}

The following individuals contributed to the preparation of this report.

\begin{tabular}{ll}
\hline Name & Contribution \\
\hline G. Ruskauff & Primary author \\
A. Holm, J. Rumbaugh & Document review \\
J. Bartel & Technical editing \\
T. Gagliano, B. Harvey & Graphic design \\
L. Sanchez & Word processing \\
\hline
\end{tabular}




\subsection{REFERENCES}

Anderson, M., and W. Woessner, 1992. Applied Groundwater Modeling, Academic Press, Orlando, Florida.

Bear et al. (J. Bear, M. Beljin, and R. Ross), 1992. Fundamentals of Ground-Water Modeling, EPA/540/S-92/005.

deMarsily, G., 1986. Quantitative Hydrogeology, Academic Press, Orlando, Florida.

DOE (U.S. Department of Energy), 1994a. Site Observational Work Plan for the UMTRA Project Site at Shiprock, New Mexico, DOE/AL/62350-158, Rev. 0. September 1994, prepared by the U.S. Department of Energy, UMTRA Project Office, Albuquerque Operations Office, Albuquerque, New Mexico.

DOE (U.S. Department of Energy), 1994b. Baseline Risk Assessment of Ground Water Contamination at the Uranium Mill Tailings Site near Shiprock, New Mexico, DOE/AL/62350-48F, Rev. 1, April 1994, prepared by the U.S. Department of Energy, UMTRA Project Office, Albuquerque Operations Office, Albuquerque, New Mexico.

DOE (U.S. Department of Energy), 1985. Remedial Action Plan and Site Conceptual Design for Stabilization of the Inactive Uranium Mill Tailings Site at Shiprock, New Mexico, UMTRA-DOE/AL-050504.0000, June 1985, prepared by the U.S. Department of Energy, UMTRA Project Office, Albuquerque Operations Office, Albuquerque, New Mexico.

Domenico and Schwartz, 1990. Physical and Chemical Hydrogeology, John Wiley \& Sons, Inc.

Duffield et al. (G. Duffield, D. Buss, and D. Stephenson), 1990. "Velocity prediction errors related to flow model calibration uncertainty," Calibration and Reliability in Groundwater Modelling (K. Kovar, ed.), IAHS Publ. 195, pp. 397-406.

Hill, M. C., 1992. A Computer Program (MODFLOWP) for Estimating Parameters of a Transient, Three-Dimensional, Ground-Water Flow Model Using Nonlinear Regression, U.S. Geological Survey Open File Report 91-848.

Konikow, L., 1978. "Calibration of ground-water models," Verification of Mathematical and Physical Models in Hydraulic Engineering, American Society of Civil Engineers, N.Y., pp.87-93.

McDonald, M., and A. Harbaugh, 1988. "A modular three-dimensional finite-difference ground-water flow model," Techniques of Water-Resources Investigations, Chapter A1, Book 6, U.S. Geological Survey, Reston, Virginia. 
McLean, J. S., and I. A. Johnson, 1987. Aquifers of the Western Mountain Area, AWRA Monograph Series, No. 14, pp. 203-217.

Neuman, S. P., 1980. "Adjoint-State Finite Element Equations for Parameter Estimation," in Proceedings of the Third International Conference on Finite Elements in Water Resources, University of Mississippi, Oxford.

Rumbaugh, J. O., and L. L. Ruskauff, 1993. "Geraghty \& Miller Modeling Survey, Analysis of May 1992 Survey Results", Geraghty \& Miller Modeling Group, Reston, Virginia.

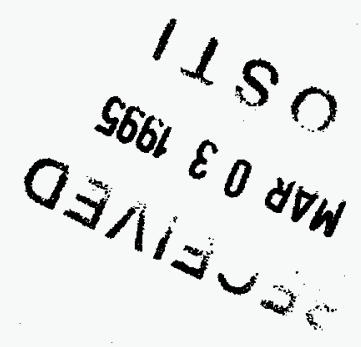

